\title{
A Study of Performance Measurement of Waqf Institution
}

\author{
Dila Fadna Sari ${ }^{1}$, Hidayatul Ihsan ${ }^{2}$, Desi Handayani ${ }^{3}$, Eliyanora ${ }^{4}$ \\ \{dilafadna@gmail.com ${ }^{1}$, hidayatul@pnp.ac.id², ci_e@yahoo.com ${ }^{3}$, norabuan93@gmail.com ${ }^{4}$ \} \\ Accounting Department, Padang State Polytechnic, Indonesia ${ }^{1,2,3,4}$
}

\begin{abstract}
This study aims at exploring and assessing the performance of a waqf institution, i.e., the West Sumatra Muhammadiyah Waqf Board (BWUMSB). In doing so, this research employs dimensions of performance measurement, which encompass efficiency, social effectiveness, maqashid al-sharia, and sustainability and growth as well as the concept of ta'bidul ashli wa tashbilul manfaah. The findings show that BWUMSB does not apply any indicators to assess the performance of its institution. It is also indicated that the revenue earned from managing waqf funds are mostly allocated for administrative expenses. Moreover, although the collection of waqf funds has increased throughout the year, the nazhirs (waqf managers) tend to invest the fund into low-risk businesses, which, in turn, causes profits to be suboptimal. These imply that BWUMSB has not been efficient in managing waqf funds for programs and operational costs. On the other hand, the accumulation of funds every year indicates that BWUMSB has been effective in collecting waqf funds. From the perspective of maqashid al-sharia, the BWUMSB has been trying to be in line with Islamic law. The sustainability and growth dimension indicates that there have been some efforts made by BWUMSB to sustain its institution and the management of waqf funds. Overall, nazhir at BWUMSB strives to safeguard the waqf property and its sustainability benefits, which is suggested by the concept of ta'bidul ashli wa tasbilul manfaah.
\end{abstract}

Keywords: Performance measurement, waqf, efficiency, social effectiveness, maqashid al-shariah, sustainability and growth, ta'bidul ashli wa tasbilul manfaah.

\section{Introduction}

Islam is a comprehensive and universal religion that covers all aspects of human life. The comprehensive nature (syumul) of Islam implies that Islam is not merely about spiritual spheres but also encompasses anything related to social life (muamalah). One of the social life matters that become the concern of Islamic teaching is the economic aspect. There are many economic instruments in Islam that can bring society to prosperity. Among other things, waqf is believed as a vital tool to achieve social welfare. The unique characteristic of waqf is that its corpus should be maintained while only the profit generated can be distributed to the beneficiaries (ta'bidul ashli wa tasbilul manfaah). 
As the world's largest Muslim-populated country, Indonesia has the potential to optimize the role of waqf. It has been documented that waqf land in Indonesia has reached 46,457.37 hectares that spread in 355,700 locations. Out of these, $18,967.44$ hectares or 223,175 locations already had waqf certificates while the remaining 27,489.93 hectares or 132,525 locations have not been certified [1]. Indeed, waqf in Indonesia needs a new paradigm in assets management. The management and development of waqf in Indonesia require a joint commitment between the Government, Islamic scholars (ulama), and the community. In this regard, the government should pay attention to the empowerment of waqf as part of improving people's welfare. Meanwhile, Islamic scholars have a role in the control of the Waqf policies hence not to contradict Islamic sharia. On the other hand, the community, including waqif (donors) and also nazhir (manager), are responsible for managing the waqf property.

The Waqf Law No. 41 of 2004 allows individuals, organizations, and legal entities to become nazirs. However, the waqf regulator is more likely to encourage the establishment of organizations or legal entities nazhir s as they are believed to perform better than individual nazhirs in managing waqf. In this case, the performance of a waqf institution cannot be seen solely from the amount of waqf collection. There must be an integrated mechanism to measure the performance of waqf institutions. The performance measurement is not only related to financial aspects because not everything in the waqf management can be quantified. A comprehensive performance appraisal encompasses financial and non-financial aspects. Therefore, this study aims to evaluate the performance of waqf institutions comprehensively with a case study design. The West Sumatra Muhammadiyah Waqf Board was, therefore, selected as the case. Further, in conducting this research, the authors adopted the dimensions of performance measurement formulated by Noordin et al. [2].

\section{Literature Review}

The existing literatures show that there have not been many studies conducted on waqf performance measurement. A study by Ihsan et al. [3] revealed that performance is part of accountability, hence it should be present in managing waqf. Although the term performance seems to be product of modernity, this study found that waqf had been a subject of assessment in the past. During its golden time in Ottoman era, a representative of Sultan, called Qadi, regularly checked the achievement of nazhirs and gave rewards or punishment on their performance.

The similar findings are also indicated by study by Ihsan et al. [4] where they conducted the investigation on accountability practice in a waqf institution. As a part of accountability mechanism, this study suggests that performance measurement is essential indicator to evaluate as to how nazhir has fulfilled the designated purpose of a waqf. Ayedh et al. [5] affirm this finding through their study on waqf accountability in Republic of Yemen.

One of the studies that employ financial indicators to measure waqf performance is a study by Sulaiman and Zakari [6]. Using the Tuckman and Chang's model, this study attempted to evaluate the financial health of waqf institutions. This study suggests the importance of adoption of performance measurement as it will determine the sustainability of waqf in the future.

Most of performance measurement indicators are related to financial measures. However, Basri [7] revealed that non-financial performance measurement could subsequently improve financial performance. He believes that the emergence of non-financial measurement 
is due to the failure of financial measures to provide all the information needed in managing an organization.

Therefore, according to Noordin et al.[2], there have been difficulties in measuring the performance of waqf institution waqf comprehensively. As far as waqf study is concerned, there is no systematic method to measure the social impact of the existence of waqf institutions. So far, performance measurement tends to be formalities from superiors to subordinates, not from norms or culture in the management of waqf institutions. Therefore, Noordin et al. came up with a formula to measure the performance of waqf, which encompasses efficiency, social effectiveness, maqasid al-sharia, and sustainability and growth. This formula is believed to cover both financial and non-financial aspects of waqf. A recent study of waqf performance measurement using the dimension proposed by Noordin et al. [2] has been conducted by Defiva [8]. This research employed a case study design at the Waqf Daarut Tauhid Bandung. This research concludes that the dimensions of this performance measurement can be applied in Waqf Daarut Tauhid Bandung.

\section{Research Methods}

This research employs a qualitative approach with a case study design. The selected case was West Sumatra Muhammadiyah Waqf Board (BWUMSB), as the pioneer of cash waqf management in West Sumatra. There are two sources of data in this study, that is, primary data and secondary data. While the primary data were collected through semi-structured interviews and observation, the secondary data is gathered from the financial statements of BWUMSB. The semi-structured interviews and observation were addressed the qualitative measures of waqf performance, i.e., maqashid al-sharia, and sustainability and growth, while the financial statements were used to assess quantitative indicators, that is, efficiency and social effectiveness.

\section{Case Profile}

Badan Wakaf Uang Muhammadiyah Sumatera Barat (BWUMSB) was established in July 2011 as part of the West Sumatra Muhammadiyah's organ. Its establishment was motivated by the need of alternative funds to assist those people who are in need. As indicated in its name, the main activity of BWUMSB is to manage cash waqf. The waqf collected will be invested in any productive bushiness scheme, and the profit generated will the allocated to four programs, i.e., scholarships, humanitarian assistance, free health services, dakwah, and remote area development. There are two investment schemes for waqf fund, that is in the micro finance institution and agricultural investment.

\section{Case Findings}

\subsection{Performance of BWUMSB in managing waqf}

In general, BWUMSB does not apply any mechanisms to measure its performance in managing waqf. Therefore, the authors measured BWUMSB performance by using the dimension of performance measurement proposed by Noordin et al. [2].

\subsubsection{Efficiency}

Efficiency is defined as the organization's ability to utilize the minimum resources to achieve maximum outcome. Noordin et al. have not provided detail measurements to assess the 
efficiency dimension. Therefore, to operationalize the efficiency dimension, the authors adopted indicators proposed by the charity navigator [9]. Further, the assessment of the efficiency ratio of BWUMSB is elaborately discussed below:

a. Program Cost Efficiency Ratio

Efficiency scores are obtained from a comparison between program costs and total expenditures in the same year. According to the efficiency indicators provided by the charity navigator [9], BWUMSB has not been efficient in managing waqf funds for program financing. The minimum score of efficiency should be at 0.65 , while the efficiency score of BWUMSB is at 0.16 .

b. Operational Efficiency Ratio

The operational efficiency ratio is obtained from a comparison between operating costs and total expenditures. Based on the indicator provided by the charity navigator, the minimum score of operational efficiency is 0.25 . Meanwhile, from the assessment of BWUMSB, the score is 0.80 , which indicates that this institution has not been efficient.

c. Waqf fundraising efficiency ratio

Waqf fundraising efficiency ratio is calculated from the comparison between fundraising costs over the total waqf fund collected. The average score of fundraising efficiency at BWUMSB from 2016 to 2018 is 0.01 . According to the charity navigator, the fundraising efficiency ratio between $0-0.03$ is valued 10 points, which means efficient.

The summary of the abovementioned ratios are presented in table 1 .

Table 1 Calculation of BWUMSB efficiency

\begin{tabular}{|c|r|r|r|r|r|}
\hline \multirow{2}{*}{ Ratio } & \multicolumn{3}{|c|}{ Efficiency Scores } & \multirow{2}{*}{ Remarks } & \\
\cline { 2 - 4 } & 2016 & 2017 & 2018 & Average & \\
\hline Program Cost Efficiency & 0.24 & 0.13 & 0.10 & 0.16 & Not efficient \\
\hline Operational Efficiency & 0.75 & 0.82 & 0.84 & 0.80 & Not efficient \\
\hline Waqf fundraising efficiency & 0.00 & 0.02 & 0.01 & 0.01 & Efficient \\
\hline
\end{tabular}

\subsubsection{Social Effectiveness}

Social effectiveness is related to the organisation's ability to fulfil society's needs with the available resources. There are two types of social effectiveness, that is, internal effectiveness and external effectiveness. This study measures the BWUMSB's internal effectiveness based on the amount of waqf collection, while external effectiveness was calculated based on channeling the benefits of managing waqf funds.

\section{a. Internal Effectiveness}

Table 2 shows an increased amount of collection from 2016 to 2017 and from 2017 to 2018 respectively. The effectiveness score of the collection in 2017 is 130.71, while in 2018 it was 172.34. It indicates that BWUMSB has been very effective in collecting waqf funds. 
b. External Effectiveness

Table 2 shows that, in 2017, BWUMSB obtained an effectiveness score at 86.32, which falls under a quite effective category. Meanwhile, in 2018, the score is 98.21 , which means effective category.

Tabel 2 Calculation of BWUMSB Social Effectiveness

\begin{tabular}{|r|l|r|r|r|r|r|}
\hline \multirow{2}{*}{ No } & Items & \multicolumn{3}{|c|}{ Amount } & Effectiveness scores \\
\cline { 2 - 7 } & Collection & 2016 & 2017 & 2018 & 2017 & 2018 \\
\hline 2 & Distribution & $8,080,869,500$ & $139,689,450$ & $240,734,400$ & 130.71 & 172.34 \\
\hline
\end{tabular}

\subsubsection{Maqashid al-sharia}

Maqashid al-sharia (sharia objectives) refers to as to how someone's or organisation's activities and programs have been in line with the objectives of Islamic sharia. There are five objectives of sharia, that is hifz ad-din (maintenance of religion), hifz an-nafs (maintenance of the soul), hifz al-'aql (care of mind), hifz al-nasl (care of descendants), and hifz al-mal (care of treasure). The objective of sharia in waqf can be seen from three perspectives, i.e., waqif, nazhir and beneficiaries.

Islam is a comprehensive religion and way of life. None of the Islamic sharia can be removed. Hence, maintaining the practice of waqf, is part of maintaining the religion (hifz Ad-Din). In the BWUMSB, the effort to maintain the religion can also be found in dakwah (preaching) program, where part of waqf income was used to support Islamic dakwah to the remote area.

One of the programs conducted by BWUMSB is a free health service. Apparently, this is in line with the second objective of sharia, i.e., hifz an-nafs (maintenance of the soul). The third objective of sharia, i.e. hifz al-'aql (care of mind), is observable from the effort made by BWUMSB in educating the Muslim society. Traditionally, waqf is known as endowing fixed assets. The new paradigm of waqf, where money can also be donated as waqf, requires extensive education to the public.

The free health service is not only fulfilled the hifz an-nafs objective, but also the fourth objective, that is hifz al-nasl (care of descendants). It is noticeable that one of the patients acknowledged that the service provided by the clinic had helped her in controlling her pregnancy regularly.

The fifth objective of sharia, hifz al-mal (care of treasure), appears from the nature of waqf as amal jariyah (perpetual charity). It is mentioned in the hadith that the reward for those who donate their assets as waqf will continue despite he or she has passed away. In this sense, the implication of maintaining the treasure is not solely about its physical existence but goes beyond it, that is, the benefit of the assets.

\subsubsection{Sustainability and growth}

The sustainability and growth dimension can be seen from two perspectives, BWUMSB as a waqf institution and the way BWUMSB managing waqf. Concerning the status of BWUMSB as a waqf institution, this study evaluates its sustainability and growth from several indicators, which encompass legal compliance, institutional financing, preparation of financial statement and staff recruitment.

So far, BWUMSB has not registered at the Indonesian Waqf Board (BWI). In fact, the Waqf law has mandated all nazhirs to register at BWI, as BWI is ultimate waqf regulator 
in Indonesia. This is, of course will threaten the sustainability of BWUMSB as a waqf manager. With regard to institutional financing, BWUMSB should pay more attention to the source of operational expenses. Most of the operational expenses were from waqf profit. The problem is that, BWUMSB spent more than $10 \%$ of the waqf profit. According to the Waqf law, nazhir is entitled only up to $10 \%$ out of the profit.

BWUMSB has recorded all waqf transactions. However, the recording and preparation of financial reports have not based on the generally accepted accounting standards. This is, of course, should be a concern for BWUMSB to improve waqf administration in the future. In addition to this, BWUMSB does not have any systematic mechanism for staff recruitment. Indeed, for the sustainability of the institution, BWUMSB should consider having a precise arrangement of staff recruitment.

Pertaining to the way BWUMSB managing waqf, the sustainability aspect it is observable from the effort in maintaining the waqf corpus. BWUMSB realised that the waqf corpus cannot diminish. Hence, most of the investment made is in a low-risk investments and businesses. The sustainability and growth can also be seen from the increasing amount of waqf collection over the years.

\subsection{Performance from the perspective of Ta'bidul Ashli Wa Tasbilul Manfaah}

This section will further elaborate on the abovementioned findings from the standpoint of Ta'bidul Ashli Wa Tasbilul Manfaah. It is undeniable truth that the main principle of waqf is to keep the corpus (principal) and the profit should be distributed to the designated purposes. The calculation of efficiency ratio indicates that BWUMSB has not been efficient in managing waqf. Out of three ratios, only waqf fundraising is indicated being efficient. Meanwhile, Program Cost Efficiency and Operational Efficiency are indicated have not been efficient. According to the treasurer, the main problem faced by BWUMSB is the lack of operational financing.

"It is the operational cost the reason why we grew slowly. We, at BWUMSB, are not free to use funds like LazisMU [amil zakat], which can allocate all of its funds. We are only allowed to use the benefits [of the waqf]."

Although BWUMSB has not been efficient, the way BWUMSB manages waqf assets so far has fulfilled the principle of Ta'bidul Ashli, which is maintaining the corpus of waqf.

The social effectiveness ratios also indicate that BWUMSB is more concern about maintaining the waqf corpus (Ta'bidul Ashli) instead of distributing the benefit (Tasbilul Manfaah). This is perhaps because the income generated from waqf investment has not considered enough to cover various expenses of the programs. Both principles, Ta'bidul Ashli and Tasbilul Manfaah are moderately observable in the dimensions of Maqashid al sharia and Sustainability and growth, although cannot be measured quantitatively.

\section{Conclusion}

It is undeniable truth that performance measurement is essential for any organizations, including waqf institutions. The dimension of the performance appraisal for a waqf should cover both financial and non-financial aspects. This study attempts to explore and asses the performance of a waqf institution i.e., BWUMSB in managing waqf. Four indicators of performance proposed by Noordin et al. [2] are therefore employed in this study. Those four 
indicators are efficiency, social effectiveness, maqashid al-sharia, and sustainability and growth. Besides that, this paper also discusses the performance of waqf from the principle of Ta'bidhul Asli Wa Tashbilul Manfaah, which is the basic concept of waqf.

Although the findings of the study indicate that not all performance indicators have been sufficiently met BWUMSB, generally, the principle of Ta'bidhul Asli Wa Tashbilul Manfaah is present at BWUMSB in managing waqf. This study implies that the waqf regulator should come up with standardized performance indicators, thus can encourage nazhir s to improve their performance in managing waqf.

\section{References}

[1] Kemenag, "Data Tanah wakaf," 2019. [Online]. Available: http://siwak.kemenag.go.id/.

[2] N. H. Noordin, S. N. Haron, and S. Kassim, "Developing a comprehensive performance measurement system for waqf institutions," Int. J. Soc. Econ., vol. 44, no. 7, pp. 921-936, 2017.

[3] H. Ihsan, Eliyanora, and Y. Septriani, "Accountability mechanisms for awqaf institutions: Lessons learnt from the history," J. King Abdulaziz Univ. Islam. Econ., vol. 29, no. 1, pp. 41-54, 2016.

[4] H. Ihsan, M. Sulaiman, N. M. Alwi, and M. A. Adnan, "A study of accountability practice in Dompet Dhuafa Waqf of Indonesia," J. King Abdulaziz Univ. Islam. Econ., vol. 30, no. 2, pp. 13-32, 2017.

[5] A. Ayedh, A. Echchabi, and H. Ihsan, "Waqf accountability in the Republic of Yemen: An empiRical analysis," Qudus Int. J. Islam. Stud., vol. 6, no. 2, pp. 161-180, 2018.

[6] M. Sulaiman and M. Alhaji Zakari, "Financial sustainability of state waqf institutions (SWIs) in Malaysia," J. Islam. Account. Bus. Res., 2019.

[7] Y. M. Basri, "Pengukuran Kinerja Non Finansial Dalam Meningkatkan Kinerja Finansial : Study Literatur,” J. Akunt., vol. 3, no. 2, pp. 114-126, 2015.

[8] J. A. Defiva, “Analisis Kinerja Lembaga Wakaf Daarut Tauhid Bandung,” Politeknik Negeri Padang, 2018.

[9] S. M. Sorensen and D. L. Kyle, "Valuable Volunteers," Strategic Finance, pp. 39-45, 2007. 